\title{
ANALISIS KAUSALITAS ANTARA KEBIJAKAN INVESTASI, DIVIDEN, DAN PENDANAAN PADA PERUSAHAAN MANUFAKTUR YANG LISTED DI BURSA EFEK JAKARTA
}

\author{
Oleh: \\ Muhammad Sulhan *
}

\begin{abstract}
This research try to analyze causality among investment, dividend, and financing on the listed manufacture companies at the Jakarta Stock Exchange, that can be used for making policies in the future. There are two contradictory opinions about the theory of investment, dividend, and financing policies between Modigliani \& Miller with Bhattacharya that is about asymmetry information which is showed by causality between investment, dividend, and financing policies. The contradictory opinion is very interesting to be analyzed further in this research.

This research was conducted by taking samples of manufacture companies listed at the Jakarta Stock Exchange. Sample we selected by purposive sampling, in the form of companies that have cash dividend for three years continuously. Manufacture company is chosen as the research object because manufacture company have fixed assets serving as dominant investment elements of the total company assets.

Results of this research show the negative causality between investment with dividend policies. The other result of this research show the positive causality between investment with financing policies and the positive causality between dividend with financing policies.

Implication of the results are company manager to be wiser in dividend payment, the increase of retained earning in financing patterns, and the addition of long term debt with limited borrowing capacity.
\end{abstract}

Keyword : Investment, dividend, financing, causality test. 


\section{PENDAHULUAN}

Krisis ekonomi yang terjadi di Indonesia akhir-akhir ini, menyebabkan para manajer perusahaan harus lebih berhati - hati dalam menetapkan kebijakankebijakan perusahaannya agar tetap bertahan dan tumbuh. Kebijakan - kebijakan strategis di bidang manajemen keuangan yang terkait erat dengan masalah optimalisasi nilai dan pertumbuhan perusahaan adalah bagaimana pihak manajemen mengambil kebijakan untuk dividen, investasi dan pendanaan yang sangat berpengaruh terhadap nilai perusahaan yang tampak pada harga saham di pasar modal.

Kebijakan dividen berkaitan dengan penentuan pembagian laba pendapatan perusahaan untuk dibayarkan sebagai dividen atau untuk digunakan sebagai laba ditahan untuk keperluan reinvestasi perusahaan selanjutnya. Weston dan Brigham (1994) menyatakan bahwa kebijakan dividen yang optimal (optimal dividen policy) adalah kebijakan dividen yang menekankan pada keseimbangan antara dividen saat ini (current) dan pertumbuhan perusahaan pada masa mendatang (future growth) sehingga memaksimumkan harga saham perusahaan.

Kebijakan investasi sering disebut juga capital budgeting problem, bertujuan mengalokasikan dana dalam bentuk investasi yang mendatangkan keuntungan di masa yang akan datang yang sifatnya tidak dapat diperkirakan secara pasti, karena menanggung resiko atau ketidakpastian. Resiko dan hasil yang diharapkan dari kebijakan investasi mempengaruhi pencapaian tujuan perusahaan maupun nilai perusahaan. 
Kebijakan pendanaan merupakan salah satu dari kebijakan keuangan yang berkaitan dengan masalah sumber dana yang dapat dimanfaatkan oleh perusahaan. Pendanaan perusahaan dapat diperoleh dari sumber dana internal (intern financing) dari dalam perusahaan send iri yang berasal dari operasional perusahaan berupa laba di tahan (retained earning) atau dapat juga berasal dari dana eksternal (extern financing) yang dapat diperoleh dari hutang jangka panjang (long term debt) dan dari penerbitan saham baru ( issuing new stock).

Pihak manajemen dalam menentukan kebijakan keuangan dihadapkan pada kondisi ada tidaknya keterkaitan antara ketiga kebijakan tersebut untuk mencapai suatu hasil yang optimal dalam meningkatkan nilai perusahaan. Ada dua pandangan teori kebijakan deviden, investasi dan pendanaan yang saling bertentangan. Pertama, Modigliani dan Miller (1958) berpendapat bahwa dalam pasar modal yang sempurna, kebijakan investasi dalam sebuah perusahaan tidak terpengaruh oleh cara pendanaan terhadap investasi - investsi tersebut. Bahkan, Modigliani dan Miller (1961) lebih jauh mengimpliksikan bahwa didalam asumsi pasar modal sempurna kebijakan investasi dari sebuah perusahaan tidak terpengaruh oleh kebijakan dividennya. Jadi secara keseluruhan, peneliti ini menyatakan bahwa kebijakan investasi sebuah perusahaan tidak tergantung pada kebijakan pendanaan dan dividennya. Kesimpulan semacam ini didasarkan pada sejumlah asumsi yang membatasi, terutama adanya pengharapan homogen dari peserta pasar modal yang mengimplikasikan bahwa semua pihak memiliki akses yang sama terhadap informasi (informasi simetri). Disamping itu asumsi pasar 
modal yang sempurna antara lain mengimplikasikan tidak adanya biaya transaksi dan pajak.

Ketidaksempurnaan pasar modal memunculkan teori yang kedua yang disampaikan oleh Bhattacharya (1979), Ross (1977) yang mendokumentasikan informasi asimetri yang diakibatkan oleh pengetahuan yang lebih banyak dimiliki manajer tentang prospek perusahaan mereka. Adanya asimetri informasi yang di tambah dengan ketidaksempurnaan pasar akibat biaya transaksi dan pajak, maka akan menimbulkan kemungkinan bahwa kebijakan investasi sebuah perusahaan tergantung pada kebijakan dividen dan pendanaannya.

Penelitian-penelitian empiris yang menyelidiki keterkaitan antara ketiga kebijakan ini (investasi, dividen, dan pendanaan), telah banyak dilakukan oleh banyak peneliti yang menghasilkan bermacam-macam temuan. Misalnya, penelitian oleh Fama (1974) dan Smirlock \& Marshall (1983) terhadap perusahaan-perusahaan di Amerika, dan penelitian oleh Mc Donald, Jacquillat, dan Nussenbaum (1975), serta Morgan dan Saint Pierre (1978) terhadap perusahaan-perusahaan di luar Amerika menemukan bahwa kebijakan-kebijakan investasi, dividen, dan pendanaan bersifat independen. Namun Dhrymes \& Kurz (1967), Mc Cabe (1979), Peterson \& Benesh (1983), dan Baskin (1989) menemukan bahwa kebijakan investasi tergantung pada kebijakan dividen dan pendanaannya. Begitu pula penelitian yang dilakukan oleh Mboja \& Mukherjee (1994) terhadap perusahaan Amerika dengan menggunakan model autoregressive juga menghasilkan temuan tidak adanya independensi diantara ketiga kebijakan tersebut. 


\section{Perumusan Masalah}

1. Apakah kebijakan investasi perusahaan manufaktur yang listed di BEJ dipengaruhi oleh kebijakan dividen dan kebijakan pendanaannya?

2. Apakah kebijakan dividen perusahaan manufaktur yang listed di BEJ dipengaruhi oleh kebijakan pendanaan dan kebijakan investasinya?

3. Apakah kebijakan pendanaan perusahaan manufaktur yang listed di BEJ dipengaruhi oleh kebijakan dividen dan kebijakan investasinya?

4. Apakah pengaruh kebijakan tersebut bersifat kausal atau hanya pengaruh searah saja?

\section{Tujuan}

1. Untuk mengetahui apakah kebijakan investasi perusahaan manufaktur yang listed di BEJ dipengaruhi oleh kebijakan dividen dan kebijakan pendanaannya?

2. Untuk mengetahui apakah kebijakan dividen perusahaan manufaktur yang listed di BEJ dipengaruhi oleh kebijakan pendanaan dan kebijakan investasinya?

3. Untuk mengetahui apakah kebijakan pendanaan perusahaan manufaktur yang listed di BEJ dipengaruhi oleh kebijakan dividen dan kebijakan investasinya?

4. Untuk mengetahui apakah pengaruh kebijakan tersebut bersifat kausal atau hanya pengaruh searah saja 


\section{TINJAUAN PUSTAKA}

Studi - studi empiris diantaranya dilakukan oleh Dhrymes dan Kurz (1967) untuk menguji adanya independensi antara kebijakan dividen, investasi dan pendanaan yang berasal dari hutang baru dengan menggunakan tipe analisis cross sectional dan hasilnya tidak ada independensi kebijakan. Tertarik dengan penelitian sebelumnya ini , maka Fama (1974) mencoba untuk menganalisis dengan tipe analisis time series keterkaitan antara kebijakan dividen dan investasi, dan ternyata hasilnya berbeda yaitu adanya independensi kebijakan.

Hasil penelitian Fama ini mendorong Mc. Donald Jacquillat dan Nussenbaun (1975) untuk menguji kembali penelitian dari Dhrymes dan Kurz dengan tipe analisis yang sama yaitu cross sectional dan memperoleh hasil yang berbeda yaitu adanya independensi kebijakan. Berdasarkan hasil penelitian ini pula, maka Morgan dan Saint Pierre (1978) mencoba menguji ulang terhadap hasil penelitian Fama dengan tipe analisis time series dan menghasilkan adanya independensi kebijakan.

Penelitian selanjutnya yang berkaitan dengan ketiga kebijakan tersebut dilakukan oleh Mc. Cabe. Mc. Cabe (1979) tertarik dengan penelitian sebelumnya dan mencoba untuk meneliti keterkaitan antara kebijakan deviden dan investasi serta ditambah dengan variabel pendanaan yang pada penelitian Morgan dan Saint Pierre tidak disertakan. Hasil penelitian Mc. Cabe ini menunjukkan tidak adanya independensi kebijakan.

Peterson dan Benesh (1983) yang tidak puas dengan hasil temuan dari Mc. Donald yang menggugurkan hasil penelitian dari Dhrymes dan Kurz dan mencoba 
menguji kembali hasil penelitian dari Mc. Cabe dengan tipe analisis yang sama yaitu cross sectional. Untuk itulah Peterson dan Benesh melakukan pengujian ulang dengan sample perusahaan yang cukup besar dari sebelumnya. Hasil penelitian Peterson dan Benesh ini sesuai dengan penelitian Dhrymes dan Kurz dan Mc. Cabe yaitu tidak adanya independensi kebijakan.

Penelitian selanjutnya mulai mengembangkan metode estimasinya dengan tidak hanya melihat pengaruh searah saja tetapi kausalitas kebijakannya dengan tes kausalitas. Penelitian ini dilakukan oleh Smirloc dan Marshal yang tidak hanya melihat hubungan yang searah saja antara kebijakan deviden dan investasi melainkan juga melihat kausalitas di antara kebijakan tersebut dan hasilnya membuktikan adanya independensi kebijakan. Kemudian Baskin (1989) juga melakukan penelitian dengan mengembangkan tipe analisis yang digunakan, yaitu dengan menggabungkan kedua tipe analisis (time series dan cross section), ini di karenakan adanya perbedaan antara hasil penelitian yang menggunakan tipe analisis ini, Baskin mencoba menguji keterkaitan antara kebijakan investasi, deviden, dan pendanaan. Hasil pengujiannya ini membuktikan tidak adanya independensi kebijakan.

Pengembangan metode estimasi untuk meneliti keterkaitan ketiga kebijakan tersebut, selanjutnya dilakukan oleh Mboja dan Mukherjee (1994) dengan melakukan pengujian kausalitas dengan menerapkan teknik modelling vector autoregressive (VAR), serta menggunakan tipe analisis time series dan cross section. Pengembangan metode estimasi ini di lakukan oleh Mboja dan Mukherjee, karena melihat bahwa pengaruh suatu kebijakan akan memerlukan 
rentang waktu (lag). Temuan dari penelitian Mboja dan Mukherjee menunjukkan bahwa adanya kausalitas antara kebijakan investasi dengan kebijakan dividen sebuah perusahaan yang bersifat dua arah dan negatif. Sementara itu kausalitas antara kebijakan investasi dengan kebijakan pendanaan yang yang berasal dari hutang bersifat dua arah dan positif, begitu pula kausalitas antara kebijakan dividen dengan kebijakan pendanaan yang berasal dari hutang juga bersifat dua arah dan possitif. Hasil pengujian dari Mboja dan Mukherjee ini membuktikan bahwa tidak adanya independensi di antara ketiga kebijakan tersebut.

Sedangkan penelitian terhadap adanya kausalitas antara dividen, pendanaan, dan investasi di Indonesia pernah dilakukan oleh Sudarma (1996) sebelum krisis moneter yang terjadi di Indonesia. Adapun hasil penelitian dari Sudarma menunjukkan adanya kausalitas antara kebijakan investasi dengan kebijakan dividen sebuah perusahaan yang bersifat dua arah dan positif. Temuan ini berbeda dengan hasil penelitian dari Mboja \& Mukherje yang menyatakan adanya kausalitas antara kebijakan investasi dengan kebijakan dividen yang bersifat dua arah dan positif. Perbedaan hasil temuan tersebut menunjukkan adanya penyimpangan kondisi realitas di Indonesia yang menjadi obyek dari penelitian yang dilakukan oleh Sudarma, dibandingkan dengan penelitian yang dilakukan oleh Mboja \& Mukherje dengan realitas kond isi di Amerika.

Temuan dalam penelitian Sudarma ini memberikan indikasi bahwa kenaikan pembayaran dividen merupakan isyarat (sinyal) adanya kenaikan investasi tanpa menunggu pemupukan laba di tahan. Hal ini investasi di biayai dari hutang jangka panjang dan emisi saham baru. Kondisi ini menunjukkan banyak perusahaan di 
Indonesia yang tidak melakukan pecking order dalam melakukan kegiatan investasinya.

Kemudian hasil lain dari penelitian Sudarma ini menunjukkan bahwa adanya kausalitas antara kebijakan investasi dengan kebijakan pendanaan kebijakan investasi yang bersifat dua arah dan positif. Begitu juga antara kebijakan dividen dengan kebijakan pendanaan menunjukkan adanya kausalitas yang bersifat dua arah dan positif. Temuan ini menunjukkan hasil yang sama dengan temuan dari penelitian Mboja \& Mukherje.

Pada penelitian ini digunakan tiga variabel yaitu investasi, dividen, dan pendanaan. Ini berbeda dengan penelitian terdahulu khususnya penelitian dari Fama (1974), Morgan \& Saint Pierre (1978), Peterson \& Benesh(1983) yang hanya menggunakan dua variabel kebijakan saja yaitu dividen dan investasi dan hanya terfokus pada pengaruh searah saja. Penelitian ini menggunakan tiga variabel kebijakan di atas sekaligus dikarenakan dari ketiga kebijakan tesebut saling terkait dan ada kecenderungan terjadi kausalitas antara kebijakan yang satu dengan yang lainnya. Disamping itu pula dalam penelitian ini pada variabel pendanaan dimasukkan komponen laba ditahan dan modal saham, sedangkan dalam penelitian terdahulu di atas umumnya pada variabel pendanaan hanya hutang jangka panjang saja seperti pada penelitian mboja \& Mukherjee dan sejenisnya. Akhirnya pada penelitian ini adalah untuk melihat adanya kausalitas antara ketiga kebijakan tersebut ( investasi, dividen, dan pendanaan) pada perusahaan manufaktur yang listed di bursa efek Jakarta khus usnya setelah adanya krisis moneter yang melanda Indonesia. 


\section{Hipotesis}

1. Kebijakan investasi perusahaan manufaktur yang listed di BEJ dipengaruhi oleh kebijakan dividen dan kebijakan pendanaannya .

2. Kebijakan dividen perusahaan manufaktur yang listed di BEJ dipengaruhi oleh kebijakan pendanaan dan kebijakan investasinya .

3. Kebijakan pendanaan perusahaan manufaktur yang listed di BEJ dipengaruhi oleh kebijakan dividen dan kebijakan investasinya .

4. Ada kausalitas antara kebijakan investasi dengan kebijakan dividen perusahaan manufaktur yang listed di BEJ yang bersifat negatif.

5. Ada kausalitas antara kebijakan investasi dengan kebijakan pendanaan perusahaan manufaktur yang listed di BEJ yang bersifat positif.

6. Ada kausalitas antara kebijakan pendanaan dengan kebijakan dividen perusahaan manufaktur yang listed di BEJ yang bersifat positif.

\section{METODE PENELITIAN}

Jenis penelitian yang digunakan dalam penelitian ini adalah explanatory research yaitu penelitian yang menjelaskan hubungan kausal antara variabelvariabel melalui pengujian hipotesis dengan menggunakan analisis yang didasarkan pada laporan keuangan. Sedangkan sifat analisis penelitiannya causal comparative analytic. Sifat analisis penelitian ini di pilih karena akan menguji secara empirik pengaruh timbal balik antara kebijakan dividen, investasi, dan pendanaan pada perusahaan - perusahaan manufacture yang listed di Bursa Efek Jakarta. 


\section{Obyek dan Lokasi penelitian}

Obyek dari penelitian ini adalah perusahaan - perusahaan manufaktur yang listed di Bursa Efek Jakarta yang menerbitkan laporan keuangan selama periode penelitian dari tahun 2000 sampai dengan 31 Desember 2002. Alasan pemilihan perusahaan manufaktur, karena perusahaan manufaktur umumnya mempunyai aktiva tetap berwujud yang nilainya cukup besar sebagai komponen investasi, dibandingkan dengan perusahaan jasa dan perdagangan. Sedangkan lokasi penelitian adalah di pojok BEJ Fakultas Ekonomi Universitas Brawijaya.

\section{Populasi dan Penentuan Sampel}

Populasi dalam penelitian ini adalah perusahaan manufaktur yang go public dan telah terdaftar dalam Bursa Efek Jakarta. Berdasarkan hasil observasi awal yang telah dilakukan terhadap perusahaan manufaktur yang listed di Bursa Efek Jakarta, diperoleh sejumlah 155 perusahaan manufaktur. Dari jumlah ini dipilih perusahaan-perusahaan yang mengeluarkan dividen selama tiga tahun berturutturut selama periode penelitian ini yaitu mulai tahun 2000 sampai tahun 2002 dan dengan kriteria tersebut diperoleh sebanyak 30 perusahaan. Mengingat kecilnya jumlah populasi (30 perusahaan), maka digunakan semua anggota populasi sebagai sampel penelitian ini.

\section{Sumber Data dan Teknik Pengumpulan Data}

Data diperoleh dari sumber data sekunder yang berasal dari informasi keuangan dalam Indonesia Capital Market Directory untuk perusahaan 
manufaktur yang terdaftar di Bursa Efek Jakarta. Sebagai tambahan diperoleh data dari perspectus (laporan tahunan yang diterbitkan perusahaan yang sudah Go Public di Bursa Efek), majalah, buku, internet yang memuat informasi yang berkaitan dengan perusahaan manufaktur. Jenis data yang dikumpulkan adalah perkembangan laporan keuangan selama periode penelitian ini (2000 - 2002) dengan melakukan dokumentasi. Kemudian data disusun dengan menggunakan pooling data secara time series dan cross sectional.

\section{Identifikasi dan Definisi Operasional Variabel}

1. Variabel dividen (dividend) dengan notasi $\mathrm{D}$, yaitu dividen yang dibagikan tahunan oleh perusahaan pada para pemegang sahamnya yang merupakan hasil perkalian antara diviend per share dengan jumlah saham yang beredar. $\mathrm{D}=$ DPS x Jumlah lembar saham ysng beredar

$$
\begin{aligned}
\operatorname{dimana}: \mathrm{D} & =\text { Total dividen } \\
\mathrm{DPS} & =\text { Dividen Per Share }
\end{aligned}
$$

2. Variabel investasi (investment) dengan notasi I, yaitu pengeluaran perusahaan untuk aktiva tetap berwujud yang dipakai dalam operasi perusahaan, yang terd iri dari: gedung, mesin-mesin, dan peralatan.

$\mathrm{I}=\sum \mathrm{AT}$ berwujud

dimana $: \mathrm{I}=$ Total investasi

$$
\text { AT }=\text { Aktiva tetap }
$$

3. Variabel pendanaan (financing) dengan notasi $\mathrm{F}$, yaitu pendanaan yang digunakan oleh perusahaan untuk membiayai operasi perusahaannya dan 
dihitung secara agregat yang meliputi : hutang jangka panjang, modal saham, dan laba di tahan.

$$
\begin{array}{rlr}
\mathrm{F}=\mathrm{HJP}+\mathrm{MS} & +\mathrm{RE} \\
\text { dimana }: \mathrm{F} \quad=\text { Total pend anaan } & \mathrm{RE}=\text { Laba di tahan } \\
\mathrm{HJP} & =\text { Hutang jangka panjang } & \mathrm{MS}=\text { Modal saham }
\end{array}
$$

\section{Teknik Analisis Data}

Penelitian ini menggunakan analisis yang didasarkan pada laporan keuangan dari perusahaan manufaktur di Bursa Efek Jakarta dengan melakukan tabulasi variabel dividen, investasi, dan pendanaan selama periode penelitian pada sampel perusahaan manufaktur. Kemudian penelitian ini dilakukan tes kausalitas dengan menggunkan model autoregressive dengan bantuan program SPSS dan Excel for Windows. Model autoregressive adalah model yang memasukkan nilai masa lalu dari variabel dependen (lag) sebagai variabel bebas. Model autoregressive secara umum dirumuskan sebagai berikut (Gujarati : 1995) :

$$
\begin{aligned}
Y_{\mathrm{t}}=\alpha+\beta_{1} \mathrm{X}_{\mathrm{t}}+\beta_{2} \mathrm{Y}_{\mathrm{t}-1}+\mu_{\mathrm{t}} & \\
\text { Dimana : } \mathrm{Y}=\text { Variabel dependen } & \beta_{1,} \beta_{2}=\text { Koefisien regresi } \\
\mathrm{X}=\text { Variabel independen } & \mathrm{t}=\text { Waktu ke } \mathrm{t}
\end{aligned}
$$

Berdasarkan model tersebut di atas, maka persamaan model autoregreesive yang akan dianalisis dalam penelitian ini adalah sebagai berikut sebagai berikut :

$$
\begin{aligned}
& I_{t}=\alpha+\beta_{1} D_{t}+\beta_{2} F_{t}+\beta_{3} I_{t-1}+\mu_{t} \\
& D_{t}=\alpha+\beta_{1} I_{t}+\beta_{2} F_{t}+\beta_{3} D_{t-1}+\mu_{t} \\
& F_{t}=\alpha+\beta_{1} I_{t}+\beta_{2} D_{t}+\beta_{3} F_{t-1}+\mu_{t}
\end{aligned}
$$




$$
\begin{array}{rlrl}
\operatorname{dimana}: \mathrm{I} & =\text { Investasi } & \beta_{1,} \beta_{2,}, \beta_{3}=\text { Koefisien regresi } \\
\mathrm{D} & =\text { Dividen } & \mathrm{t} \quad=\text { Waktuke } \mathrm{t} \\
\mathrm{F} & =\text { Pendanaan } & &
\end{array}
$$

Kemudian untuk membuktikan hipotesis 1,2, dan 3, maka dilakukan Uji $\mathrm{t}$ dan Uji F terhadap ketiga persamaan model autoregreesive di atas. Sedangkan untuk mengetahui adanya kausalitas antar variabel atau hanya bersifat searah dan sekaligus untuk membuktikan hipotesis 4,5, dan 6, maka dapat dilihat dari koefisien dari masing-masing variabel yang signifikan (Gujarati, 1995), misalnya :

a) Jika koefisien $\mathrm{D}$ terhadap $\mathrm{I} \neq 0$ dan koefisien I terhadap $\mathrm{D} \neq 0$, maka berarti terdapat kausalitas antara Dividen dengan Investasi.

b) Jika koefisien $\mathrm{D}$ terhadap $\mathrm{I} \neq 0$ dan koefisien $\mathrm{I}$ terhadap $\mathrm{D}=0$, atau koefisien $\mathrm{D}$ terhadap $\mathrm{I}=0$ dan koefisien $\mathrm{I}$ terhadap $\mathrm{D} \neq 0$, maka berarti terdapat hubungan satu arah yaitu antara Dividen ke Investasi atau Investasi ke Dividen.

c) Jika koefisien $\mathrm{D}$ terhadap $\mathrm{I}=0$ dan koefisien $\mathrm{I}$ terhadap $\mathrm{D}=0$, maka berarti antara Dividen dengan Investasi bebas antara satu dengan yang lain.

\section{HASIL ANALISIS DAN PEMBAHASAN}

\section{a.Hasil regresi terhadap persamaan model autoregressive untuk fungsi Investasi}

Hasil analisis regresi terhadap persamaan model autoregressive untuk fungsi Investasi, kami sajikan dalam tabel berikut : 
Tabel 3. Hasil regresi terhadap persamaan model autoregressive untuk fungsi Investasi

\begin{tabular}{|l|l|l|l|}
\hline Dependent & \multicolumn{1}{|c|}{$\begin{array}{c}\text { Dividen } \\
(\mathrm{D})\end{array}$} & $\begin{array}{l}\text { Pendanaan } \\
(\mathrm{F})\end{array}$ & $\mathrm{I}-1$ \\
\hline Invesatsi (I) & $-0,0824$ & 0,156 & 0,943 \\
& $(-0,0960)$ & $(7,055)^{* * *}$ & $(44,626)^{* * *}$ \\
\hline $\mathrm{R}^{2}$ & 0,987 & \\
\hline $\mathrm{F}$ & 2127,049 & \\
\hline
\end{tabular}

Sumber data : Lampiran 2

Keterangan : - Angka dalam kurung merupakan nilai t-hitung

- Nilai t-tabel adalah t $0,10=1,67, \mathrm{t} 0,05=2,00, \mathrm{t} 0,01=2,66$

- *** Signifikan pada tingkat $1 \%$

** Signifikan pada tingkat $5 \%$

* Signifikan pada tingkat $10 \%$

Dari tabel hasil regresi di atas terlihat bahwa kebijakan investasi dipengaruhi oleh kebijakan pendanaan dan kebijakan investasi pada periode tahun sebelumnya secara positif dengan tingkat signifikansi sebesar $1 \%$. Pengaruh pendanaan terhadap investasi yang bersifat positif ini berarti apabila pendanaan naik sebesar Rp1000, maka akan berakibat naiknya investasi sebesar Rp156. Sedangkan untuk dividen sebenarnya mempunyai koefisien negatif ynag menunjukkan pengaruh dividen terhadap investasi bersifat negatif, namun karena t-hitung lebih kecil dari t-tabel, maka pengaruh dividen terhadap investasi tidak signifikan dan dengan kata lain dapat dikatakan bahwa kebijakan investasi tidak dipengaruhi secara signifikan oleh kebijakan dividen. Akhirnya dari tabel di atas dapat disimpulkan bahwa hipotesis 1 yang menyatakan bahwa kebijakan investasi dipengaruhi oleh kebijakan dividen dan pendanaan, ternyata pengaruh kebijakan dividen tidak signifikan (tidak berpengaruh) terhadap kebijakan invesatsi, sedangkan pengaruh pendanaan signifikan terhadap invesatsi. 


\section{b.Hasil regresi terhadap persamaan model autoregressive untuk fungsi}

\section{Dividen}

Hasil analisis regresi terhadap persamaan model autoregressive untuk fungsi dividen, kami sajikan dalam tabel berikut :

Tabel 4. Hasil regresi terhadap persamaan model autoregressive untuk fungsi dividen.

\begin{tabular}{|l|l|l|l|}
\hline Dependent & \multicolumn{1}{|c|}{ Investasi (I) } & $\begin{array}{l}\text { Pendanaan } \\
(\mathrm{F})\end{array}$ & $\mathrm{D}-1$ \\
\hline Dividen (D) & $-0,08337$ & 0,232 & $-0,381$ \\
& $(-3,292)^{* * *}$ & $(8,630)^{* * *}$ & $(-3,982)^{* * *}$ \\
& & & \\
\hline $\mathrm{R}^{2}$ & 0,583 & \\
\hline $\mathrm{F}$ & 40,068 & \\
\hline
\end{tabular}

Sumber data : Lampiran 3

Dari tabel hasil regresi di atas terlihat bahwa kebijakan dividen dipengaruhi oleh kebijakan investasi dan kebijakan dividen pada periode tahun sebelumnya secara negatif dengan tingkat signifikansi sebesar $1 \%$. Pengaruh investasi terhadap dividen yang bersifat negatif ini berarti apabila investasi naik sebesar Rp1000 , maka akan berakibat turunnya dividen sebesar Rp83,37. Kemudian dari tabel diatas juga terlihat bahwa kebijakan dividen dipengaruhi oleh kebijakan pendanaan secara positif dengan tingkat signifikansi $1 \%$. Pengaruh pendanaan terhadap dividen yang bersifat positif ini berarti apabila pendanaan naik sebesar Rp1000, maka akan berakibat naiknya investasi sebesar Rp232. Akhirnya dari tabel diatas dapat disimpulkan bahwa dari hipotesis 2 yang menyatakan bahwa kebijakan dividen dipengaruhi oleh kebijakan investasi dan pendanaan terbuk ti dalam penelitian ini. 


\section{c.Hasil regresi terhadap persamaan model autoregressive untuk fungsi pendanaan}

Hasil analisis regresi terhadap persamaan model autoregressive untuk fungsi pendanaan, kami sajikan dalam tabel berikut :

Tabel 5. Hasil regresi terhadap persamaan model autoregressive untuk fungsi pendanaan.

\begin{tabular}{|l|l|l|l|}
\hline Dependent & \multicolumn{1}{|c|}{ Investasi (I) } & Dividen (D) & $\mathrm{F}-1$ \\
\hline Pendanaan $(\mathrm{F})$ & 0,119 & 2,205 & 0,866 \\
& $(2,812)^{* * *}$ & $(16,044)^{* * *}$ & $(18,237)^{* * *}$ \\
\hline $\mathrm{R}^{2}$ & 0,956 & \\
\hline $\mathrm{F}$ & 623,733 & \\
\hline
\end{tabular}

Sumber data : Lampiran 4

Dari tabel hasil regresi di atas terlihat bahwa kebijakan Pendanaan dipengaruhi oleh kebijakan investasi, kebijakan dividen dan kebijakan pendanaan pada periode tahun sebelumnya secara positif dengan tingkat signifikansi sebesar $1 \%$. Pengaruh investasi terhadap pendanaan yang bersifat positif ini berarti apabila investasi naik sebesar Rp1000, maka akan berakibat naiknya pendanaan sebesar Rp119. Sedangkan pengaruh dividen terhadap pendanaan yang bersifat positif ini berarti apabila dividen naik sebesar Rp1000, maka akan berakibat naiknya pendanaan sebesar Rp2205. Akhirnya dari tabel diatas dapat disimpulkan bahwa dari hipotesis 3 yang menyatakan bahwa kebijakan pendanaan dipengaruhi oleh kebijakan investasi dan dividen terbukti dalam penelitian ini.

\section{d. Analisis kausalitas antara kebijakan invesatsi, dividen, dan pendanaan}

Seperti yang telah kami hipotesiskan pada hipotesis 4,5, dan 6 tentang adanya kausalitas antara kebijakan investasi, dividen, dan pendanaan, maka 
pada bagian ini kami akan mengulas lebih lanjut hal tersebut seperti yang kami rangkum dalam tabel berikut:

Tabel.6. Rangkuman kausalitas antara kebijakan Investasi, dividen, dan Pendanaan

\begin{tabular}{|c|c|c|l|}
\hline Dependent & Investasi (I) & Dividen (D) & $\begin{array}{l}\text { Pendanaan } \\
(\mathrm{F})\end{array}$ \\
\hline Investasi (I) & - & $\begin{array}{c}-0,0824 \\
(-0,0960)\end{array}$ & $\begin{array}{l}0,156 \\
(7,055)^{* * *}\end{array}$ \\
\hline Dividen (D) & $-0,08337$ & - & 0,232 \\
& $(-3,292)^{* * *}$ & & $(8,630)^{* * *}$ \\
\hline Pendanaan (F) & 0,119 & 2,205 & - \\
& $(2,812)^{* * *}$ & $(16,044)^{* * *}$ & \\
\hline
\end{tabular}

Sumber data : Lampiran 2,3 , dan 4

\section{Kausalitas antara kebijakan investasi dengan kebijakan dividen}

Dari tabel diatas tampak bahwa koefisien D terhadap $\mathrm{I} \neq 0$ dan koefisien I terhadap $\mathrm{D} \neq 0$, maka berarti secara umum ada kecenderungan kausalitas antara kebijakan investasi dengan kebijakan dividen yang bersifat negatif. Namun karena tingkat signifikansi dari koefisien D terhadap I rendah (tidak signifikan), maka dapat dikatakan pengaruh dividen terhadap investasi terlalu kecil dan dapat dianggap tidak ada pengaruh dari dividen terhadap investasi. Sehingga dari tabel diatas dapat disimpulkan bahwa antara kebijakan investasi dan dividen terjadi hubungan searah yaitu dividen dipengaruhi oleh investasi.

Dari temuan dalam penelitian ini, maka hipotesis 4 yang menyatakan bahwa ada kausalitas antara kebijakan investasi dengan kebijakan dividen ternyata tidak terbukti karena hanya pengaruh investasi terhadap dividen yang signifikan, sedangkan pengaruh dividen terhadap investasi tidak signifikan. 
Maksud dari temuan ini bahwa dividen dipengaruhi investasi yang bersifat negatif adalah karena peningkatan pengeluaran investasi terutama dari dana dengan menggunakan retained earning apabila perusahaan melakukan ekspansi, maka akan memyebabkan Dividen Payout Ratio (DPR) akan mendekati nol yang berarti dividen mengalami penurunan.

Hasil temuan ini berbeda dengan hasil penelitian dari Sudarma (1996) yang menyatakan adanya kausalitas antara kebijakan investasi dan kebijakan dividen yang bersifat dua arah dan positif. Perbedaan ini dimungkinkan karena kondisi realitas di Indonesia sebelum krisis ekonomi, dimana pasar modal di Indonesia masih belum di dukung oleh infrastruktur hukum sebagai instrumen untuk melindungi investor terutama investor individual. Di samping itu pula perbedaan ini juga menunjukkan kondisi emiten pada waktu itu (sebelum krisis ekonomi) dapat melakukan praktek pemberian pinjaman oleh bank dalam satu grup perusahaannya sendiri. Adanya praktek semacam ini, perusahaan dalam memperoleh pinjaman tidak perlu adanya pemupukan laba di tahan untuk meningkatkan kapasitas peminjamannya (borrowing capacity). Hal ini juga senada dengan yang dikatakan Ary Suta (2000) tentang tantangan dan kondisi pasar modal di Indonesia sebelum krisis ekonomi mengenai rendahnya profesionalisme pihak - pihak yang terkait dalam pasar modal Indonesia.

Sedangkan hasil penelitian ini adanya kecenderungan kausalitas yang bersifat dua arah dan negatif (walaupun untuk pengaruh kebijakan dividen terhadap investasi tidak signifikan). Hal ini menunjukkan setelah terjadinya 
krisis ekonomi di Indonesia, pemerintah lebih berhati-hati dalam menentukan infrastruktur hukum dalam pasar modal Indonesia, sehingga pihak emiten tidak dapat lagi bertindak seperti sebelum krisis ekonomi, misalnya melakukan praktek pemberian pinjaman oleh bank dalam satu grup perusahaannya untuk melakukan ekspansi investasi tanpa menunggu pemupukan laba ditahan. Ini menunjukkan proses perbaikan pasar modal Indonesia setelah krisis ekonomi khususnya yang berkaitan dengan profesionalisme pelaku pasar modal mulai berjalan. Peningkatan profesionalisme dan infra struktur hukum di pasar modal di Indonesia harus terus diupayakan. Hal ini penting karena profesionalisme dapat meningkatkan objektivitas, kewajaran, dan efisiensi dan keterbukaan di pasar modal. Oleh karena itu dari hasil penelitian ini yaitu adanya kecenderungan kausalitas yang bersifat negatif di atas dapat menunjukkan bahwa kenaikan investasi mulai didahului oleh adanya pemupukan laba ditahan perusahaan. Sehingga apabila perusahaan melakukan ekspansi investasi dari dana laba ditahan, maka akan menyebabkan divident payout ratio akan mendekati nol yang berarti dividen akan mengalami penurunan.

Hasil temuan penelitian ini pula berbeda dengan hasil penelitian dari Mboja dan Mukherje (1984) yang menyatakan adanya kausalitas yang bersifat dua arah dan negatif secara signifikan antara kebijakan investasi dan kebijakan dividen. Tetapi dalam penelitian ini untuk pengaruh dari kebijakan dividen terhadap investasi yang bersifat negatif masih belum signifikan. Hal ini belum dapat dianggap sebagai argumen bahwa pasar modal di Indonesia relatif 
sempurna dan tidak ada asimetri informasi, tetapi hal ini lebih dimungkinkan karena kondisi pasar modal di Indonesia dalam masa transisi setelah adanya krisis ekonomi yang terjadi di Indonesia, dibandingkan dengan kondisi dari pasar modal di Amerika yang diteliti oleh Mboja dan Mukherje.

\section{Kausalitas antara kebijakan investasi dengan pendanaan}

Dari tabel diatas tampak bahwa koefisien $\mathrm{F}$ terhadap $\mathrm{I} \neq 0$ dan koefisien I terhadap $\mathrm{F} \neq 0$, serta pengaruh kedua koefisien ini signifikan. Ini berarti ada kausalitas antara kebijakan investasi dengan kebijakan pendanaan yang bersifat positif.

Dari temuan dalam penelitian ini, maka hipotesis 5 yang menyatakan bahwa ada kausalitas antara kebijakan investasi dengan pendanaan pada perusahaan manufaktur yang listed di BEJ yang bersifat positif terbukti. Hasil penelitian ini berarti sesuai dengan penelitian dari Surdarma (1996) dan Mboja \& Mukhenjee (1994) pada perusahaan Amerika yang menyatakan adanya kausalitas antara kebijakan investasi dengan pendanaan yang bersifat positif.

Makna dari temuan ini adalah bahwa perusahaan manufaktur yang listed di BEJ sudah memanfaatkan peluang investasi aktiva tetap terhadap proyek-proyek dengan NPV tinggi dan telah memanfaatkan cadangan borrowing capacity dengan melakukan pinjaman jangka panjang dan juga telah memupuk cadangan borrowing capacity dengan melakukan akumulasi dari laba di tahan dan modal saham dengan melakukan right issuer (penerbitan saham baru) untuk meningkatkan sumber pendanaannya sebagai akibat dari meningkatnya investasi perusahaan. Tetapi yang perlu diwaspadai oleh 
perusahaan-perusahaan yang listed di Bursa Efek Jakarta yang masih menggunakan right issuer sebagai upaya untuk meningkatkan cadangan borrowing capacity-nya, menurut Mboja dan Mukherje (1994) dalam informasi asimetri apabila perusahaan melakukan right issuer (penerbitan saham baru) adalah merupakan kabar buruk bagi investor karena secara teoritis perusahaan akan lebih menguntungkan menjual obligasi. Emisi saham baru dalam informasi asimetri akan menimbulkan agency cost yang lebih besar dibandingkan dengan menerbitkan obligasi, dan dilain pihak dengan adanya perusahaan melakukan right issuer, bagi investor yang rasional mempunyai dugaan yang kurang baik terhadap emiten.

Di sisi lain dengan adanya penurunan pendanaan khususnya dengan pengurangan hutang jangka panjang yang diakibatkan besarnya pinjaman perusahaan mendekati atau bahkan melewati borrowing capacity-nya, sehingga dengan adanya penurunan pendanaan ini umumnya merupakan awal dari penurunan dalam investasi.

\section{Kausalitas antara kebijakan dividen dengan pendanaan}

Dari tabel di atas tampak bahwa koefisien $F$ terhadap $D \neq 0$ dan $D$ terhadap $\mathrm{F} \neq 0$, serta pengaruh kedua koefisien ini signifikan. Ini berarti ada kausalitas antara kebijakan dividen dengan pendanaan yang bersifat positif.

Dari temuan dalam penelitian ini, maka hipotesis 6 yang menyatakan ada kausalitas antara kebijakan investasi dengan pendanaan pada perusahaan manufaktur yang listed di BEJ yang bersifat positif terbukti. Hasil ini juga sesuai dengan penelitian dari Sudarma (1996) dan Mboja \& Mukhenjee (1994) 
yang menyatakan adanya kausalitas antara kebijakan dividen dengan pendanaan.

Makna dari temuan ini adalah bahwa perusahaan manufaktur yang listed di BEJ dalam melakukan kebijakan menaikkan pembayaran dividen perusahaan, merupakan sinyal pendanaan investasi di masa yang akan datang membatasi aksesnya dari laba ditahan, dan peningkatan kebutuhan pendanaannya akan dipenuhi dari hutang jangka panjang. Dengan meningkatnya pinjaman seiring dengan peningkatan pembayaran dividen, pihak manajemen perusahaan akan melakukan pemupukan borrowing capacity melalui emisi saham baru agar secara agregat pendanaan perusahaan mengalami kenaikan seiring dengan kenaikan pembayaran dividen tersebut. Di sisi lain dengan adanya peningkatan pendanaan perusahaan baik dari sumber dana internal maupun eksternal, dalam kondisi normal akan menaikkan kemampuan perusahaan dalam membayar dividen.

\section{KESIMPULAN}

Hasil analisis dalam penilitian ini menunjukkan bahwa kebijakan investasi perusahaan manufaktur yang listed di BEJ secara signifikan dipengaruhui oleh pendanaan, sedangkan pengaruh dividen terhadap investasi ternyata tidak signifikan. Kemudian hasil lain dalam penelitian ini juga menunjukkan kebijakan dividen perusahaan manufaktur yang listed di BEJ secara signifikan dipengaruhi oleh kebijakan investasi dan pendanaan. Begitu juga 
dengan kebijakan pendanaan dipengaruhi secara signifikan oleh kebijakan investasi dan dividen.

Dalam hal kausalitas dari kebijakan investasi, dividen dan pendanaan, pada penelitian ini menunjukkan bahwa antara kebijakan investasi dengan dividen bersifat satu arah yaitu dividen dipengaruhi oleh investasi, sedangkan investasi tidak dipengaruhi oleh dividen. Hasil lain dari penelitian ini juga menunjukkan adanya kausalitas antara kebijakan investasi dengan pendanaan yang bersifat positif, sedangkan antara dividen dengan pendanaan menunjukkan adanya kausalitas yang bersifat positif.

Akhirnya kami menyadari bahwa hasil penelitian ini masih jauh dari sempurna karena masih adanya keterbatasan-keterbatasan. Untuk itu perlu dilakukan perbaikan-perbaikan baik ddalam hal alat analisis, ruang lingkup penelitian, populasi, sampel sehingga kesimpulan yang diambil akan lebih jauh mencerminkan realitas yang ada. 


\section{DAFTAR PUSTAKA}

Ary Suta, I Putu Gede,2000, Menuju Pasar Modal Modern, Yayasan SAD Satria Bhakti, Cetakan 1, Jakarta.

Bhattacharya, S, 1979, Imperfect Information, Dividend Policy and The "bird in the hand "Fallacy, Bell Journal of Economics, 10 page 59-70.

Brigham, Eugene and Louis C Gapensky, 1996, Intermediate Financial Management, Fifth edition, The Dryden Press, Philadelpia.

Gujarati, N Damodar, 1995, Basic Econometrics, Third Edition, Mc Graw Hill International editions, Economics Series.

Husnan, Suad, 1996, Dasar-Dasar Teori Portofolio dan Analisis Sekuritas, Edisi III, Yogyakarta.

Jensen, Michael C. and William H. Meckling, 1976, Theory of The Firm : Managerial Behavior, Agency Cost and Ownership Structure, Journal of Finance.

Jones, Charles P, 2000,Investments, Analysis and Management, seventh Edition, John Willy \& Son.

Donnald Mc, Jcquillat and Nussenbaum, 1975, Dividend, Investment and Financing Decisions Empirical Evidence on French' Firms, Journal of Financial and Quantitative Analysis, page 741-754.

Miller, Merton H. and Franco Modigliani, 1961, Dividend Policy, Growth, and The Valuation of Shares, Journal of Business, 34, Okt.

Mougue, and Mukherjee, 1994, An Investigation into The Causality among Firms' dividend, Investment and Financing Decision, The Journal of Financial Research, Vol XVII No : 4 page 512-530.

Myers, Stephen C, 1984, Capital Structure Puzzle, National Bureau of Economic Research, Massachusetts.

Peterson, Pamela P. and Benesh Gary A, 1983, A Reexamination of the Empirical Relationship Between Investment and Financing Decision, Journal of Financial and Quantitative Analysis Vol. 18 No. 4, December 1983. 
Sharpe, William E, G. Alexander, J.V. Bailey, Investasi, Edisi Bahasa Indonesia, Prenhallindo, Jakarta.

Smirlock, Michale and Marshall William, 1983, An Examination of The Empirical Relationship Between The Dividend and Investmet Decisions, The Journal of Finance Vol. XXXVIII, December 1983.

Solimun, 2002, Multivariate Analysis, Structural Equation Modelling, Lisrell dan Amos, Universitas Negeri Malang Press..

Sudarma, Made, 1996, Analisis Kausalitas Keputusan Dividen, Investasi, dan Pendanaan pada Perusahaan-Perusahaan di BES, Wacana Vol 1 No. 2.

Warsono, 2001, Keputusan Keuangan Jangka Panjang, Ed isi Ketiga, UMM Press Malang.

Weston, J Fred and Brigham, F. Eugene, 1994, Essential of Management Finance, The Dryden Press, a Advison of Holt, Rinehart and Winston, Inc.

* Muhammad Sulhan, SE., MM., Dosen Fakultas Ekonomi UIN Malang 